Virginia Commonwealth University VCU Scholars Compass

\title{
Peginterferon Alfa-2a in Patients with Chronic Hepatitis $\mathrm{C}$ and Cirrhosis
}

\author{
E. Jenny Heathcote \\ University of Health Network \\ Mitchell L. Shiffman \\ Virginia Commonwealth University \\ W. Graham E. Cooksley \\ Royal Brisbane Hospital \\ See next page for additional authors
}

Follow this and additional works at: http://scholarscompass.vcu.edu/vcuhealth_pubs Part of the Medicine and Health Sciences Commons

From The New England Journal of Medicine, Heathcote, E. J., Shiffman, M. L., Cooksley, W. G. E. et al., PEGINTERFERON ALFA-2a IN PATIENTS WITH CHRONIC HEPATITIS C AND CIRRHOSIS, Vol. 343, Page 1673, Copyright (C) 2000 Massachusetts Medical Society. Reprinted with permission.

\section{Downloaded from}

http://scholarscompass.vcu.edu/vcuhealth_pubs/22

This Article is brought to you for free and open access by the VCU Health at VCU Scholars Compass. It has been accepted for inclusion in VCU Health Publications by an authorized administrator of VCU Scholars Compass. For more information, please contact libcompass@vcu.edu. 
Authors

E. Jenny Heathcote, Mitchell L. Shiffman, W. Graham E. Cooksley, Geoffrey M. Dusheiko, Samuel S. Lee, Luis Balart, Robert Reindollar, Rajender K. Reddy, Teresa L. Wright, Amy Lin, Joseph Hoffman, and Jean De Pamphilis 


\title{
PEGINTERFERON ALFA-2a IN PATIENTS WITH CHRONIC HEPATITIS C AND CIRRHOSIS
}

\author{
E. Jenny Heathcote, M.D., Mitchell L. Shiffman, M.D., W. Graham E. Cooksley, M.D., \\ Geoffrey M. Dusheiko, M.D., Samuel S. Lee, M.D., Luis Balart, M.D., Robert Reindollar, M.D., \\ Rajender K. Reddy, M.D., Teresa L. Wright, M.D., Amy Lin, M.S., Joseph Hoffman, M.D., \\ and Jean De Pamphilis, Ph.D.*
}

\begin{abstract}
Background Chronic hepatitis C virus (HCV) infection in patients with cirrhosis is difficult to treat. In patients with chronic hepatitis $C$ but without cirrhosis, once-weekly administration of interferon modified by the attachment of a 40-kd branched-chain polyethylene glycol moiety (peginterferon alfa-2a) is more efficacious than a regimen of unmodified interferon. We examined the efficacy and safety of peginterferon alfa-2a in patients with HCV-related cirrhosis or bridging fibrosis.

Methods We randomly assigned 271 patients with cirrhosis or bridging fibrosis to receive subcutaneous treatment with 3 million units of interferon alfa-2a three times weekly (88 patients), $90 \mu \mathrm{g}$ of peginterferon alfa-2a once weekly (96), or $180 \mu \mathrm{g}$ of peginterferon alfa-2a once weekly (87). Treatment lasted 48 weeks and was followed by a 24-week follow-up period. We assessed efficacy by measuring HCV RNA and alanine aminotransferase and by evaluating liverbiopsy specimens. A histologic response was defined as a decrease of at least 2 points on the 22-point Histological Activity Index.
\end{abstract}

Results In an intention-to-treat analysis, HCV RNA was undetectable at week 72 in 8 percent, 15 percent, and 30 percent of the patients treated with interferon alfa-2a and with $90 \mu \mathrm{g}$ and $180 \mu \mathrm{g}$ of peginterferon alfa-2a, respectively $(\mathrm{P}=0.001$ for the comparison between $180 \mu \mathrm{g}$ of peginterferon alfa-2a and interferon alfa-2a). At week 72, alanine aminotransferase concentrations had normalized in 15 percent, 20 percent, and 34 percent of patients, respectively $(P=0.004$ for the comparison between $180 \mu \mathrm{g}$ of peginterferon alfa-2a and interferon alfa-2a). In the subgroup of 184 patients with paired liver-biopsy specimens, the rates of histologic response at week 72 were 31 percent, 44 percent, and 54 percent, respectively $(P=0.02$ for the comparison between $180 \mu \mathrm{g}$ of peginterferon alfa-2a and interferon alfa-2a). All three treatments were similarly tolerated.

Conclusions In patients with chronic hepatitis C and cirrhosis or bridging fibrosis, $180 \mu \mathrm{g}$ of peginterferon alfa-2a administered once weekly is significantly more effective than 3 million units of standard interferon alfa-2a administered three times weekly. (N Engl J Med 2000;343:1673-80.)

(C2000, Massachusetts Medical Society.
I NTERFERON has had a fundamental role in the treatment of patients with chronic hepatitis $\mathrm{C}$ virus (HCV) infection. In patients with cirrhosis, interferon, either alone or in combination with ribavirin, has been used cautiously, largely because it may exacerbate the patients' neutropenia and thrombocytopenia. ${ }^{1}$ In large trials of interferonbased therapies, the proportion of patients with $\mathrm{HCV}$ related advanced liver disease has been small, ${ }^{2-6}$ and we are aware of only two studies that have focused exclusively on such treatment in patients with HCVrelated cirrhosis. 7,8

To overcome some of the drawbacks of interferon, a modified form of the drug, called peginterferon alfa-2a, was developed by attaching a 40 -kd branchedchain polyethylene glycol moiety to interferon alfa2a. ${ }^{9-11}$ Recent data ${ }^{12}$ suggest that the sustained virologic response achieved with peginterferon alfa- $2 \mathrm{a}$ is similar to that observed for interferon alfa- $2 \mathrm{a}$ in combination with ribavirin in patients with hepatitis C. ${ }^{13}$ In addition, the tolerability of peginterferon is similar to that of the unmodified drug. ${ }^{12}$ We compared the efficacy and safety of two doses of peginterferon alfa-2a, each given once weekly, with the efficacy and safety of a standard regimen of unmodified interferon alfa-2a in patients with hepatitis $\mathrm{C}$ and cirrhosis or bridging fibrosis.

\section{METHODS}

\section{Patients}

Patients who had chronic HCV infection and biopsy-proved liver cirrhosis or bridging fibrosis and who had not previously been treated with interferon were eligible for the study if the following two conditions were met: the serum alanine aminotrans-

From the Department of Medicine, University Health Network, Toronto Western Hospital, Toronto (E.J.H.); the Hepatology Section, Department of Medicine, Medical College of Virginia, Richmond (M.L.S.); the Department of Medicine, Royal Brisbane Hospital, Brisbane, Australia (W.G.E.C.); the Clinical Research Department, Department of Medicine, Royal Free Hospital, London (G.M.D.); the Department of Medicine, Heritage Medical Research Clinic, Calgary, Alta., Canada (S.S.L.); the Department of Medicine, Louisiana State University Health Sciences Center, New Orleans (L.B.); Carolinas Center for Liver Disease, Department of Medicine, Charlotte, N.C. (R.R.); the Center for Liver Diseases, Department of Medicine, University of Miami School of Medicine, Miami (R.K.R.); the Gastroenterology Unit, Department of Medicine, Veterans Affairs Medical Center, San Francisco (T.L.W.); and Hoffmann-LaRoche, Nutley, N.J. (A.L., J.H., J.D.). Address reprint requests to Dr. Heathcote at the University Health Network, Toronto Western Hospital, 399 Bathurst St., Toronto, ON M5T 2S8, Canada.

*The other members of the study group are listed in the Appendix. 
ferase concentration had been abnormal on two occasions during the preceding six months, and a liver biopsy had been performed during the preceding year. Criteria for exclusion were the presence of other liver diseases, decompensated cirrhosis, human immunodeficiency virus infection, psychiatric conditions, seizure disorders, severe cardiac disease, retinopathy, cancer, a neutrophil count below 1500 per cubic millimeter, a platelet count below 75,000 per cubic millimeter, and an alpha-fetoprotein concentration above $100 \mathrm{ng}$ per milliliter.

\section{Study Design}

This open-label, randomized, parallel-dose study was conducted by the Pegasys International Study Group at 30 centers in the United States, Canada, Australia, and the United Kingdom between September 1997 and October 1999. The study was approved by the ethics committees at each center, and all the patients provided written informed consent. The trial was designed by F. HoffmannLaRoche and by expert hepatologists in conjunction with the health authorities in each country. F. Hoffmann-LaRoche was responsible for monitoring adherence to the International Conference on Harmonization guidelines ${ }^{14}$ and for monitoring the analysis of data collected by the investigators.

Patients who met the criteria for entry were randomly assigned to receive, in a 1:1:1 ratio, interferon alfa-2a (Roferon-A, F. Hoffmann-LaRoche, Basel, Switzerland) at a dose of 3 million units given subcutaneously three times weekly or peginterferon alfa-2a (Pegasys, F. Hoffmann-LaRoche) at a dose of $90 \mu \mathrm{g}$ or $180 \mu \mathrm{g}$ given subcutaneously once weekly. Randomization was performed according to center, in blocks of six patients, and random assignments were made according to a computer-generated scheme managed by Applied Logistic Associates (Houston). Patients administered the study drug subcutaneously on an outpatient basis for 48 weeks and then were followed for the next 24 weeks.

Laboratory tests, including assessments of plasma HCV RNA levels and serum alanine aminotransferase concentrations, viral genotyping, and histologic evaluation of biopsy specimens, were performed at central laboratories. Pretreatment biopsy specimens were examined without blinding before randomization and were subsequently coded and evaluated in parallel with those obtained at week 72 by pathologists who were unaware of the patients' treatment assignments. HCV genotyping was performed by sequence analysis of a portion of the $5^{\prime}$ untranslated region of the viral genome at the end of the study. ${ }^{15}$ Safety was assessed by analyzing the occurrence of adverse events, changes in vital signs, and the results of laboratory tests recorded at weeks $1,2,4,6$, and 8 of the study and then every 4 weeks for the remainder of the 72 week study period.

The protocol guidelines allowed dose modification (a 25,50 , or 75 percent reduction in the assigned dose) for patients who had important adverse events or important abnormalities in laboratory values. If a patient received more than three consecutive reduced doses or more than a total of six reduced doses, the dose could not subsequently be increased. Patients were withdrawn from the study if they missed four consecutive weeks of treatment or if an investigator was concerned about their safety.

\section{Assessment of Efficacy}

The primary end points were sustained virologic and biochemical responses. A sustained virologic response was defined as undetectable levels of HCV RNA ( $<100$ copies per milliliter) on analysis (Cobas Amplicor HCV Test [version 2.0], Roche Diagnostics, Branchburg, N.J.) at the end of the follow-up period. A sustained biochemical response was defined as an alanine aminotransferase value below the upper limit of the normal range at the end of the follow-up period. Other end points included virologic and biochemical responses at the end of the 48 -week treatment period. Liver-biopsy specimens were evaluated for changes from values at the beginning of treatment (base line) in the score on the 22-point Histological Activity Index, where inflammation is graded from 0 (none) to 18 (severe) and fibrosis is graded from 0 (none) to 4 (cirrhosis). ${ }^{16} \mathrm{~A}$ histologic response at week 72 was defined as a decrease of at least 2 points in the total score on this index (fibrosis and inflammation scores combined, with a fibrosis score of 3 indicating bridging fibrosis).

\section{Statistical Analysis}

In comparisons of the peginterferon groups with the interferon group, all categorical variables were analyzed with use of the Cochran-Mantel-Haenszel test, with stratification according to center. To control the overall probability of a type I error ( 5 percent), a two-sided significance level of 0.025 was used for the two pairwise treatment comparisons (peginterferon alfa- $2 \mathrm{a}$ at each of two doses vs. interferon alfa-2a). All end points (except for changes from base-line histologic findings) were evaluated by intentionto-treat analysis. The analysis of histologic response included only patients who underwent both a pretreatment biopsy and a biopsy at week 72 . The analysis of safety included all the patients who received at least one dose of study medication and who underwent at least one assessment of safety during the study.

\section{RESULTS}

\section{Characteristics of the Patients}

Of the 397 patients screened, 271 met the criteria for entry and underwent randomization. The main reasons for exclusion from the study were histologic features that did not suggest cirrhosis or bridging fibrosis (67 patients), a low platelet count (12), and a normal alanine aminotransferase concentration (10); 37 patients were excluded for other reasons. Two patients assigned to interferon alfa- $2 \mathrm{a}$ did not receive treatment, and one assigned to $180 \mu \mathrm{g}$ of peginterferon alfa-2a elected alternative therapy; all three were included in the intention-to-treat analysis of efficacy. Characteristics of the patients at base line are summarized in Table 1. All base-line characteristics, including factors associated with treatment outcome, were similar among the three groups.

Of the 271 eligible patients, 88 were randomly assigned to treatment with 3 million units of interferon alfa-2a, and 96 and 87 were randomly assigned to treatment with $90 \mu \mathrm{g}$ and $180 \mu \mathrm{g}$ of peginterferon alfa- $2 \mathrm{a}$, respectively. Treatment was completed by 64,78 , and 67 patients, respectively, and follow-up was completed by 68,79 , and 74 patients. Patients who discontinued drug therapy were encouraged to remain in the study for assessments through week 72. The main reasons for withdrawal were adverse events, failure to return or refusal of treatment, insufficient therapeutic effects, or laboratory abnormalities (Table 2).

\section{Virologic Response}

The rates of sustained virologic response (the response at week 72) were 8 percent, 15 percent, and 30 percent in patients assigned to unmodified interferon alfa- $2 \mathrm{a}, 90 \mu \mathrm{g}$ of peginterferon alfa- $2 \mathrm{a}$, and 180 $\mu \mathrm{g}$ of peginterferon alfa- $2 \mathrm{a}$, respectively $(\mathrm{P}=0.001$ for the comparison between $180 \mu \mathrm{g}$ of peginterferon alfa- $2 \mathrm{a}$ and interferon alfa- $2 \mathrm{a}$ [Table 3$])$. A response to therapy at week 12 predicted a sustained response; at week 12 , all of the 26 patients who had a sustained 
Table 1. Characteristics of the Patients at Base Line.*

\begin{tabular}{|c|c|c|c|}
\hline \multirow[t]{2}{*}{ Characteristic } & \multirow[t]{2}{*}{$\begin{array}{l}\text { INTERFERON } \\
\text { ALFA-2a } \\
(\mathrm{N}=88)\end{array}$} & \multicolumn{2}{|c|}{ Peginterferon Alfa-2a } \\
\hline & & $\begin{array}{c}90 \mu \mathrm{g} \\
(\mathrm{N}=96)\end{array}$ & $\begin{array}{l}180 \mu \mathrm{g} \\
(\mathrm{N}=87)\end{array}$ \\
\hline Male sex - no. (\%) & $62(70)$ & $71(74)$ & $63(72)$ \\
\hline Age - yr & $46.9 \pm 7.6$ & $47.2 \pm 8.4$ & $47.1 \pm 8.7$ \\
\hline Weight — kg & $84.6 \pm 16.2$ & $86.4 \pm 18.9$ & $82.4 \pm 17.0$ \\
\hline Body-mass index $\dagger$ & $28.7 \pm 5.9$ & $28.7 \pm 5.5$ & $27.4 \pm 5.0$ \\
\hline $\begin{array}{l}\text { Race - no. (\%) } \\
\text { White } \\
\text { Black } \\
\text { Asian } \\
\text { Other }\end{array}$ & $\begin{array}{l}77(88) \\
5(6) \\
3(3) \\
3(3)\end{array}$ & $\begin{aligned} & 87(91) \\
& 1(1) \\
& 2(2) \\
& 6(6)\end{aligned}$ & $\begin{array}{l}75(86) \\
5(6) \\
2(2) \\
5(6)\end{array}$ \\
\hline Serum alanine aminotransferase (U/liter) $\ddagger$ & $104.1 \pm 72.5$ & $104.1 \pm 58.0$ & $123.3 \pm 68.9$ \\
\hline No. of HCV RNA copies $/ \mathrm{ml}-\times 10^{-6}$ & $6.3 \pm 8.4$ & $6.3 \pm 8.0$ & $5.7 \pm 8.0$ \\
\hline Histological Activity Index score $\$$ & $12.8 \pm 1.7$ & $12.7 \pm 2.1$ & $13.4 \pm 1.7$ \\
\hline $\begin{array}{l}\text { Mode of infection - no. (\%) } \\
\text { Intravenous drug use } \\
\text { Transfusion } \\
\text { Other } \\
\text { Unspecified }\end{array}$ & $\begin{array}{l}41(47) \\
14(16) \\
10(11) \\
23(26)\end{array}$ & $\begin{aligned} 47 & (49) \\
25 & (26) \\
8 & (8) \\
16 & (17)\end{aligned}$ & $\begin{aligned} 42 & (48) \\
28 & (32) \\
9 & (10) \\
8 & (9)\end{aligned}$ \\
\hline $\begin{array}{l}\text { Histologic diagnosis - no. (\%)\| } \\
\text { Cirrhosis } \\
\text { Bridging fibrosis }\end{array}$ & $\begin{array}{l}67(76) \\
21(24)\end{array}$ & $\begin{array}{l}76(79) \\
19(20)\end{array}$ & $\begin{array}{l}69(79) \\
18(21)\end{array}$ \\
\hline $\begin{array}{l}\text { HCV genotype } \\
\text { l } \\
\text { la } \\
\text { lb } \\
\text { Other than } 1 \\
2 \\
3 \\
4 \\
\text { Other or unknown }\end{array}$ & $\begin{array}{l}47(53) \\
28(32) \\
19(22) \\
41(47) \\
12(14) \\
27(31) \\
0 \\
2(2)\end{array}$ & $\begin{aligned} 58 & (60) \\
27 & (28) \\
31 & (32) \\
38 & (40) \\
7 & (7) \\
26 & (27) \\
2 & (2) \\
3 & (3)\end{aligned}$ & $\begin{array}{l}48(55) \\
33(38) \\
15(17) \\
39(45) \\
14(16) \\
20(23) \\
1(1) \\
4(5)\end{array}$ \\
\hline
\end{tabular}

*Plus-minus values are means \pm SD. Because of rounding, not all percentages total 100 .

†Body-mass index was calculated as the weight in kilograms divided by the square of the height in meters.

$\ddagger$ For each patient, the average of the two pretreatment values meeting the entry criteria was calculated.

\$The score is based on the evaluation of the pretreatment biopsy specimen.

TOther modes of infection included use of drugs other than intravenous drugs, occupational exposure, sexual exposure, and other percutaneous infections.

$\|$ The histologic diagnosis is not shown for one patient assigned to receive $90 \mu \mathrm{g}$ of peginterferon alfa- $2 \mathrm{a}$, because subsequent blinded review of the biopsy specimen obtained at base line showed that the fibrosis score was less than 3 .

response to $180 \mu \mathrm{g}$ of peginterferon alfa-2a had had a decrease in viral load by a factor of at least 100 as compared with base line, and 23 of them had had undetectable HCV RNA.

Peginterferon alfa-2a was also associated with a higher rate of virologic response at the end of treatment (week 48) (Table 3). HCV RNA was undetectable at week 48 in 14 percent of the patients assigned to receive interferon alfa- $2 \mathrm{a}$, as compared with 42 percent of the patients assigned to receive peginterferon alfa- $2 \mathrm{a}$ at a dose of $90 \mu \mathrm{g}$ and 44 percent of the patients assigned to receive it at a dose of $180 \mu \mathrm{g}$ $(\mathrm{P}=0.001$ for the comparison between each dose of peginterferon alfa-2a and interferon alfa-2a). Although the virologic rate of response at the end of treatment was similar with the two doses of peginterferon alfa- $2 \mathrm{a}$, the response was more likely to be sustained with the $180-\mu \mathrm{g}$ dose.

\section{Biochemical Response}

A biochemical response was more likely to be sustained with the higher dose of peginterferon alfa-2a (Table 3). The rates of biochemical response at week 72 were 15 percent, 20 percent, and 34 percent in patients assigned to receive interferon alfa- $2 \mathrm{a}, 90 \mu \mathrm{g}$ of peginterferon alfa- $2 \mathrm{a}$, and $180 \mu \mathrm{g}$ of peginterfer- 
Table 2. Rates of Discontinuation of Treatment AND Dose Modification.*

\begin{tabular}{|c|c|c|c|}
\hline \multirow[t]{2}{*}{ VARIABLE } & \multirow[t]{2}{*}{$\begin{array}{l}\text { INTERFERON } \\
\text { ALFA-2a } \\
(\mathrm{N}=\mathbf{8 8})\end{array}$} & \multicolumn{2}{|c|}{$\begin{array}{l}\text { Peginterferon } \\
\text { Alfa-2a }\end{array}$} \\
\hline & & $\begin{array}{c}90 \mu \mathrm{g} \\
(\mathrm{N}=96)\end{array}$ & $\begin{array}{l}180 \mu \mathrm{g} \\
(\mathrm{N}=87)\end{array}$ \\
\hline & \multicolumn{3}{|c|}{ number (percent) } \\
\hline \multicolumn{4}{|l|}{ Discontinuation of treatment } \\
\hline Due to adverse events & $7(8)$ & $7(7)$ & $11(13)$ \\
\hline Due to laboratory abnormality & $2(2)$ & $4(4)$ & $1(1)$ \\
\hline $\begin{array}{l}\text { Due to insufficient therapeutic } \\
\text { response }\end{array}$ & $5(6)$ & $2(2)$ & $1(1)$ \\
\hline Other reasons $\dagger$ & $10(11)$ & $5(5)$ & $7(8)$ \\
\hline \multicolumn{4}{|l|}{ Dose modification $\ddagger$} \\
\hline Due to neutropenia & $12(14)$ & $9(9)$ & $9(10)$ \\
\hline Due to thrombocytopenia & $5(6)$ & $17(18)$ & $16(18)$ \\
\hline Due to adverse event & $12(14)$ & $2(2)$ & $12(14)$ \\
\hline
\end{tabular}

*Dose modification was defined as the reduction or omission of one or more doses.

†Other reasons included administrative factors, refusal of treatment, failure to return for additional treatment, and protocol violation.

‡One or more doses were modified or were not given. on alfa- $2 \mathrm{a}(\mathrm{P}=0.004$ for the comparison between $180 \mu \mathrm{g}$ of peginterferon alfa- $2 \mathrm{a}$ and interferon alfa- $2 \mathrm{a}$ ). Normalization of alanine aminotransferase at week 48 occurred in significantly more of the patients assigned to peginterferon alfa- $2 \mathrm{a}$ at either dose than of those assigned to unmodified interferon (Table 3 ).

The percentages of patients who had both a biochemical and a virologic response at week 72 were identical to the percentages who had a virologic response at that time (Table 3).

\section{Histologic Response}

Most of the 271 patients enrolled had cirrhosis at base line (Table 1). As is common with other trials in patients with liver disease, ${ }^{2,3}$ nearly one third of the patients did not return for second biopsies. Among the 184 patients with paired liver biopsies, the proportion who had a histologic response was lower among the patients assigned to receive unmodified interferon (31 percent) than among those assigned to $90 \mu \mathrm{g}$ of peginterferon alfa- $2 \mathrm{a}(44$ percent $[\mathrm{P}=0.22])$ and those assigned to $180 \mu \mathrm{g}(54$ percent $[\mathrm{P}=0.02])$

Table 3. Virologic, Biochemical, and Histologic Responses. *

\begin{tabular}{|c|c|c|c|c|c|}
\hline \multirow[t]{2}{*}{ VARIABLE } & \multirow[t]{2}{*}{$\begin{array}{l}\text { INTERFERON } \\
\text { ALFA-2a } \\
(\mathbf{N}=\mathbf{8 8})\end{array}$} & \multicolumn{2}{|c|}{ Peginterferon Alfa-2a } & \multicolumn{2}{|c|}{ P Value } \\
\hline & & $\begin{array}{l}90 \mu \mathrm{g} \\
(\mathrm{N}=96)\end{array}$ & $\begin{array}{l}180 \mu \mathrm{g} \\
(\mathrm{N}=87)\end{array}$ & $\begin{array}{c}90 \mu \mathrm{g} \\
\text { PEGINTERFERON } \\
\text { ALFA-2a Vs. } \\
\text { INTERFERON } \\
\text { ALFA-2a }\end{array}$ & $\begin{array}{c}180 \mu \mathrm{g} \\
\text { PEGINTERFERON } \\
\text { ALFA-2a Vs. } \\
\text { INTERFERON } \\
\text { ALFA-2a }\end{array}$ \\
\hline \multicolumn{6}{|c|}{ number (percent) } \\
\hline \multicolumn{6}{|l|}{ Virologic response } \\
\hline Week 48 & $12(14)$ & $40(42)$ & $38(44)$ & 0.001 & 0.001 \\
\hline Week 72 & $7(8)$ & $14(15)$ & $26(30)$ & 0.27 & 0.001 \\
\hline \multicolumn{6}{|l|}{ Biochemical response } \\
\hline Week 48 & $19(22)$ & $34(35)$ & $34(39)$ & 0.03 & 0.02 \\
\hline Week 72 & $13(15)$ & $19(20)$ & $30(34)$ & 0.47 & 0.004 \\
\hline \multicolumn{6}{|c|}{$\begin{array}{l}\text { Combined virologic and } \\
\text { biochemical response }\end{array}$} \\
\hline Week 48 & $9(10)$ & $30(31)$ & $25(29)$ & 0.001 & 0.004 \\
\hline Week 72 & $7(8)$ & $14(15)$ & $26(30)$ & 0.27 & 0.001 \\
\hline \multirow{2}{*}{\multicolumn{6}{|c|}{ Histologic response† }} \\
\hline & $17 / 55$ & $27 / 61(44)$ & $37 / 68(54)$ & 0.22 & 0.02 \\
\hline
\end{tabular}

*The assessments of efficacy were carried out by intention-to-treat analysis and included all enrolled patients, regardless of whether they withdrew from the study prematurely or discontinued treatment. A virologic response was defined as an undetectable level of HCV RNA $(<100$ copies per milliliter). A biochemical response was defined as an alanine aminotransferase value below the upper limit of normal. A histologic response was defined as a decrease of at least 2 points in the total score on the Histological Activity Index (on which a score of 3 indicates bridging fibrosis, and a score of 4 cirrhosis).

†Values are the numbers of patients with a histologic response divided by the total number with paired biopsy specimens. 
(Table 3). A histologic response correlated with a sustained virologic response; among the patients with a virologic response at week 72,80 percent of those assigned to receive interferon alfa-2a also had a histologic response, as did 100 percent of those assigned to $90 \mu \mathrm{g}$ of peginterferon alfa- $2 \mathrm{a}$ and 88 percent of those assigned to the 180- $\mu \mathrm{g}$ dose. The virologic response was similar among patients with bridging fibrosis or cirrhosis. A histologic response was seen in 26 percent, 33 percent, and 35 percent, respectively, of patients who did not have a sustained virologic response. The histologic response also correlated with the biochemical response at week 72: 40 percent, 79 percent, and 82 percent of the patients who had a biochemical response to interferon alfa-2a or peginterferon alfa-2a at $90 \mu \mathrm{g}$ or $180 \mu \mathrm{g}$, respectively, also had a histologic response.

\section{Correlation of Base-Line Characteristics with Virologic Response}

The rates of sustained virologic response with respect to pretreatment variables are presented in Table 4. Treatment with peginterferon alfa- $2 \mathrm{a}$ was consistently associated with higher rates of sustained viro-

Table 4. Rates of Virologic Response at Week 72 as a Function of Base-Line Prognostic Variables.*

\begin{tabular}{|c|c|c|c|}
\hline \multirow[t]{2}{*}{ VARIABLE } & \multirow[t]{2}{*}{$\begin{array}{c}\text { INTERFERON } \\
\text { ALFA-2a } \\
(\mathrm{N}=\mathbf{8 8}) \dagger\end{array}$} & \multicolumn{2}{|c|}{ Peginterferon Alfa-2a } \\
\hline & & $\begin{array}{c}90 \mu \mathrm{g} \\
(\mathrm{N}=96)\end{array}$ & $\begin{array}{l}180 \mu \mathrm{g} \\
(\mathrm{N}=87)\end{array}$ \\
\hline & \multicolumn{3}{|c|}{ no. with response/total no. (\%) } \\
\hline \multicolumn{4}{|c|}{ Alanine aminotransferase quotient $\ddagger$} \\
\hline$\leqslant 3$ & $2 / 48(4)$ & $8 / 52(15)$ & $7 / 28(25)$ \\
\hline$>3$ & $5 / 40(12)$ & $6 / 44(14)$ & $19 / 59(32)$ \\
\hline \multicolumn{4}{|l|}{ HCV RNA level (copies/ml) } \\
\hline$\leqslant 2,000,000$ & $2 / 41(5)$ & $10 / 45(22)$ & $16 / 43(37)$ \\
\hline$>2,000,000$ & $4 / 45(9)$ & $4 / 51(8)$ & $10 / 44(23)$ \\
\hline \multicolumn{4}{|l|}{ HCV genotype } \\
\hline l & $1 / 47(2)$ & $3 / 58(5)$ & $6 / 48(12)$ \\
\hline la & $0 / 28$ & $1 / 27(4)$ & $3 / 33(9)$ \\
\hline $1 b$ & $1 / 19(5) \$$ & $2 / 31(6)$ & $3 / 15(20)$ \\
\hline Other than 1 or unknown & $6 / 41(15)$ & $11 / 38(29)$ & $20 / 39(51)$ \\
\hline \multicolumn{4}{|c|}{ Total Histological Activity Index score } \\
\hline$\leqslant 10$ & $0 / 5$ & $1 / 13(8)$ & $2 / 5 \quad(40)$ \\
\hline$>10$ & $7 / 83(8)$ & $13 / 83(16)$ & $24 / 82(29)$ \\
\hline \multicolumn{4}{|l|}{ Histologic diagnosis $\|$} \\
\hline Cirrhosis & $5 / 67(7)$ & $11 / 76(14)$ & $22 / 69(32)$ \\
\hline Bridging fibrosis & $2 / 21(10)$ & $3 / 19(16)$ & $4 / 18(22)$ \\
\hline \multicolumn{4}{|c|}{$\mathrm{HCV}_{1}$ genotype in relation to RNA level } \\
\hline$\leqslant 2,000,000$ & $0 / 21$ & $3 / 26(12)$ & $3 / 19(16)$ \\
\hline$>2,000,000$ & $1 / 25(4) \S$ & $0 / 32$ & $3 / 29(10)$ \\
\hline \multicolumn{4}{|l|}{ Other than 1} \\
\hline$\leqslant 2,000,000$ & $2 / 20(10)$ & $6 / 18(33)$ & $12 / 22(55)$ \\
\hline$>2,000,000$ & $4 / 20(20)$ & $4 / 18(22)$ & $7 / 14(50)$ \\
\hline \multicolumn{4}{|l|}{ Unknown } \\
\hline$\leqslant 2,000,000$ & - & $1 / 1(100)$ & $1 / 2(50)$ \\
\hline$>2,000,000$ & - & $0 / 1$ & $0 / 1$ \\
\hline
\end{tabular}

*Values are the numbers of patients with a virologic response at week 72 divided by the numbers with the given base-line variable. A virologic response was defined as an undetectable level of HCV RNA ( $<100$ copies per milliliter).

†HCV RNA levels were not measured in the two patients in this group who did not receive treat ment.

$\ddagger$ The alanine aminotransferase quotient is the average of the alanine aminotransferase values before treatment divided by the upper limit of normal.

\$This patient elected to continue treatment with an alternative regimen of interferon alfa- $2 \mathrm{a}$ at the end of follow-up and was receiving interferon alfa-2a at the time of the assessment at week 72 .

TThe total Histological Activity Index score is the sum of two scores, one for inflammation $(0$ [none] to 18 [severe] $)$ and one for fibrosis $(0$ [none] to 4 [cirrhosis]); a fibrosis score of 3 indicates bridging fibrosis.

$\|$ The histologic diagnosis is not shown for one patient assigned to receive $90 \mu \mathrm{g}$ of peginterferon alfa- $2 \mathrm{a}$, because subsequent blinded review of the biopsy specimen obtained at base line showed that the fibrosis score was less than 3 . 
logic response among subgroups of patients defined by factors such as genotype and pretreatment viral load. Among patients with cirrhosis, the rate of sustained virologic response associated with the dose of $180 \mu \mathrm{g}$ of peginterferon alfa- $2 \mathrm{a}$ was more than four times that associated with the dose of interferon alfa2a (32 percent vs. 7 percent). Among patients infected with HCV genotype 1 , the rates of sustained virologic response were 2 percent, 5 percent, and 13 percent, respectively, in those assigned to interferon alfa- $2 \mathrm{a}$ and peginterferon alfa- $2 \mathrm{a}$ at $90 \mu \mathrm{g}$ and 180 $\mu \mathrm{g}$. Treatment with $180 \mu \mathrm{g}$ of peginterferon alfa- $2 \mathrm{a}$ was more efficacious in treating infection with genotype $1 \mathrm{~b}$ than infection with genotype la (rates of virologic response at week 72, 20 percent and 9 percent). Among patients with HCV genotypes other than 1 (or with no data on genotype), the rates of sustained virologic response were 15 percent, 29 percent, and 51 percent, respectively, in patients assigned to interferon and peginterferon alfa- $2 \mathrm{a}$ at $90 \mu \mathrm{g}$ and $180 \mu \mathrm{g}$. Among patients with a combination of poor prognostic factors (infection with genotype 1 and a high viral load at base line $[>2,000,000$ copies per milliliter]), 10 percent of those assigned to $180 \mu \mathrm{g}$ of peginterferon alfa- $2 \mathrm{a}$ and none of those assigned to $90 \mu \mathrm{g}$ had a sustained virologic response.

\section{Safety}

Information about discontinuation of treatment and dose modifications is shown in Table 2. In patients with cirrhosis, exacerbation of cirrhosis-related neutropenia and thrombocytopenia is a risk associated with the use of interferon. In this study, the mean $( \pm S D)$ neutrophil counts at base line were $3400 \pm 2100,3400 \pm 1200$, and $3100 \pm 1100$ per cubic millimeter, respectively, in patients assigned to receive unmodified interferon alfa- $2 \mathrm{a}, 90 \mu \mathrm{g}$ of peginterferon alfa- $2 \mathrm{a}$, and $180 \mu \mathrm{g}$ of peginterferon alfa- $2 \mathrm{a}$. These values decreased shortly after the initiation of treatment but stabilized during treatment and then rapidly returned to base-line values after the end of treatment. The proportion of patients with a neutrophil count below 500 per cubic millimeter at any time during treatment was similar in the three groups ( 3 percent with interferon alfa- $2 \mathrm{a}$, and 3 percent and 1 percent with $90 \mu \mathrm{g}$ and $180 \mu \mathrm{g}$ of peginterferon alfa-2a, respectively). In none of the patients did a serious infection or sepsis associated with neutropenia develop. Dose modification (defined as reduction or omission of one or more doses of study medication) because of neutropenia was deemed necessary in 14 percent of the patients assigned to interferon alfa- $2 \mathrm{a}$ and 9 percent and 11 percent of those assigned to 90 $\mu \mathrm{g}$ and $180 \mu \mathrm{g}$ of peginterferon alfa- $2 \mathrm{a}$, respectively. Only rarely (in two patients receiving peginterferon alfa- $2 \mathrm{a}$ at $180 \mu \mathrm{g}$ ) was permanent dose modification necessary, and no patient discontinued treatment because of neutropenia.
In most of the patients the total platelet count decreased to some extent during treatment. At base line, the mean platelet counts were $153,000 \pm 51,300$, $162,000 \pm 54,100$, and $166,000 \pm 50,600$ per cubic millimeter in the patients assigned to interferon alfa$2 \mathrm{a}, 90 \mu \mathrm{g}$ of peginterferon alfa- $2 \mathrm{a}$, and $180 \mu \mathrm{g}$ of peginterferon alfa- $2 \mathrm{a}$. These values reached a nadir of $128,000 \pm 47,600,110,000 \pm 42,300$, and 108,000 \pm 50,100 per cubic millimeter, respectively, by week 8 . The platelet count decreased to a level below the entry criterion of 75,000 per cubic millimeter in 27 percent, 48 percent, and 46 percent of patients, respectively. The proportion of patients with a platelet count below 50,000 per cubic millimeter at any time during treatment was significantly lower among those assigned to interferon alfa-2a (7 percent) than among those assigned to peginterferon alfa-2a at $90 \mu \mathrm{g}(26$ percent, $\mathrm{P}<0.001)$ or $180 \mu \mathrm{g}$ (19 percent, $\mathrm{P}=0.04$ ). None of the patients had clinically significant bleeding associated with thrombocytopenia. Dose modification was deemed necessary because of thrombocytopenia in 6 percent, 18 percent, and 19 percent of the patients receiving interferon and $90 \mu \mathrm{g}$ and $180 \mu \mathrm{g}$ of peginterferon alfa- $2 \mathrm{a}$, respectively; permanent dose modification was necessary in 4 percent, 8 percent, and 13 percent. Discontinuation of therapy because of thrombocytopenia was infrequent (it was required in 2 percent, 4 percent, and 2 percent of patients, respectively).

In all three treatment groups, the adverse events were typical of those produced by unmodified interferon alfa. Table 5 summarizes the adverse events that were reported during treatment or within eight weeks after the end of treatment. The incidence of most of the adverse events was similar in the three treatment groups; the most commonly reported events were fatigue, headache, myalgia, rigors, and pyrexia. A higher proportion of the patients assigned to receive peginterferon alfa- $2 \mathrm{a}$ at a dose of $180 \mu \mathrm{g}$ had myalgia and inflammation at the injection site than of patients in the other two groups. Dose modification was necessary because of adverse events in 14 percent of the patients assigned to interferon alfa- $2 \mathrm{a}$ and in 2 percent and 14 percent of those assigned to peginterferon alfa-2a at $90 \mu \mathrm{g}$ and $180 \mu \mathrm{g}$, respectively. Treatment was discontinued because of adverse events in 8 percent, 7 percent, and 13 percent of patients, respectively (Table 2 ).

Four deaths were reported, one in a patient assigned to receive $90 \mu \mathrm{g}$ of peginterferon alfa- $2 \mathrm{a}$ and three in patients assigned to receive $180 \mu \mathrm{g}$. Two patients died of hepatic failure, 420 and 179 days after the end of treatment; one patient died of hepatic neoplasm, 219 days after the end of treatment; and one patient who had received $180 \mu \mathrm{g}$ of peginterferon alfa-2a died of a cerebral hemorrhage after a suspected methadone overdose, 24 days after the end of treatment. In the latter patient, the platelet count was 64,000 per cu- 
Table 5. Incidence of Adverse Events during Treatment OR Within the First Eight Weeks of Follow-up.*

\begin{tabular}{|c|c|c|c|}
\hline \multirow[t]{2}{*}{ Adverse Event } & \multirow[t]{2}{*}{$\begin{array}{l}\text { INTERFERON } \\
\text { ALFA-2a } \\
(\mathrm{N}=86)\end{array}$} & \multicolumn{2}{|c|}{$\begin{array}{l}\text { Peginterferon } \\
\text { AlfFA-2a }\end{array}$} \\
\hline & & $\begin{array}{c}90 \mu \mathrm{g} \\
(\mathrm{N}=96)\end{array}$ & $\begin{array}{l}180 \mu \mathrm{g} \\
(\mathrm{N}=86)\end{array}$ \\
\hline & \multicolumn{3}{|c|}{ number (percent) } \\
\hline Fatigue & $52(60)$ & $51(53)$ & $53(62$ \\
\hline Headache & $46(53)$ & $52(54)$ & $43(50$ \\
\hline Myalgia & $33(38)$ & $35(36)$ & $44(51)$ \\
\hline Rigors & $39(45)$ & $36(38)$ & $37(43$ \\
\hline Pyrexia & $31(36)$ & $28(29)$ & $33(38$ \\
\hline Nausea & $29(34)$ & $29(30)$ & $29(34)$ \\
\hline Upper abdominal pain & $21(24)$ & $18(19)$ & $22(26$ \\
\hline Depression & $18(21)$ & $20(21)$ & $22(26)$ \\
\hline Diarrhea & $16(19)$ & $20(2 \mathrm{l})$ & $21(24$ \\
\hline Inflammation at injection site & $12(14)$ & $14(15)$ & $27(31)$ \\
\hline Insomnia & $19(22)$ & $18(19)$ & $16(19$ \\
\hline Alopecia & $19(22)$ & $14(15)$ & $15(17)$ \\
\hline Dizziness & $14(16)$ & $19(20)$ & $13(15)$ \\
\hline Pruritus & $7(8)$ & $15(16)$ & $14(16)$ \\
\hline Vomiting & $13(15)$ & $12(12)$ & $11(13)$ \\
\hline Decreased appetite & $6(7)$ & $14(15)$ & $12(14)$ \\
\hline Cough & $4(5)$ & $10(10)$ & $15(17)$ \\
\hline Dermatitis & $6(7)$ & $8(8)$ & $15(17)$ \\
\hline Epistaxis & $12(14)$ & $11(11)$ & $6(7)$ \\
\hline Pain & $10(12)$ & $10(10)$ & $9(10)$ \\
\hline Sinusitis & $6(7)$ & $12(12)$ & $7(8)$ \\
\hline Impaired concentration & $10(12)$ & $6(6)$ & $6(7)$ \\
\hline Pain in limb & $4(5)$ & $11(11)$ & $7(8)$ \\
\hline Anxiety & $6(7)$ & $11(11)$ & $3(3)$ \\
\hline
\end{tabular}

* The adverse events listed are those that occurred in at least 10 percent of the patients. Values are based on the patients who received at least one dose of study medication.

bic millimeter on admission; subsequently, sepsis complicated by a coagulopathy developed, with a platelet count of 15,000 per cubic millimeter the day before death.

\section{DISCUSSION}

Patients with chronic HCV infection and advanced liver disease usually have poor responses to treatment with interferons. ${ }^{7,8,17,18}$ Our study found that peginterferon alfa-2a produces higher rates of virologic, biochemical, and histologic responses than unmodified interferon alfa- $2 \mathrm{a}$ among patients with chronic $\mathrm{HCV}$ infection and related compensated cirrhosis or bridging fibrosis. In most patients who had a virologic response at week 72 , this sustained response could be predicted by measurement of HCV RNA at week 12. Our results are similar to those obtained in a large trial involving patients with chronic $\mathrm{HCV}$ infection who were treated with the same formula- tion of modified interferon alfa- $2 \mathrm{a}$ and who did not necessarily have cirrhosis. ${ }^{12}$

When plasma HCV RNA is undetectable, hepatic inflammation is diminished, and further progression of liver disease may be prevented. In the current trial, more than half the patients assigned to receive $180 \mu \mathrm{g}$ of peginterferon alfa- $2 \mathrm{a}$ who had paired biopsy specimens had a histologic response at week 72 , regardless of the virologic or biochemical response. Even among patients who did not have a virologic response, more than a third had histologic improvement, suggesting that patients who do not have a virologic response may still benefit from treatment with peginterferon alfa- $2 \mathrm{a}$. This finding confirms a previous report of histologic benefit in patients who were treated with unmodified interferon and who did not have a virologic response. ${ }^{19}$

At week 48 , the percentage of patients assigned to either dose of peginterferon alfa- $2 \mathrm{a}$ who did not have a virologic response was higher than the percentage of patients in these two groups who had a biochemical response. This discordance resolved after the end of treatment and did not appear to affect the rates of histologic response. The reason for this discordance is unknown. This finding further supports the use of recently developed tests for HCV RNA, rather than measurement of alanine aminotransferase, for monitoring the efficacy of therapy in patients with chronic $\mathrm{HCV}$ infection.

Use of interferon in the treatment of patients with cirrhosis has been limited by observations that patients may frequently have associated adverse effects, particularly toxic effects on bone marrow. The patients in our study often had substantial decreases in neutrophil and platelet counts during treatment, and some of the patients in each of the three treatment groups required dose modifications. Treatment was not discontinued in any patient because of neutropenia, and thrombocytopenia necessitated discontinuation of treatment in only two of the patients assigned to the $180-\mu \mathrm{g}$ dose of peginterferon alfa- $2 \mathrm{a}$. None of the patients had a systemic infection, serious hemorrhage, or hepatic decompensation. In general, the adverse events in patients assigned to peginterferon alfa- $2 \mathrm{a}$ at either dose were typical of those seen with standard interferon. Treatment was discontinued because of adverse events in 8 percent of the patients assigned to interferon alfa- $2 \mathrm{a}$ and in 7 percent and 13 percent of those assigned to peginterferon alfa- $2 \mathrm{a}$ at $90 \mu \mathrm{g}$ and $180 \mu \mathrm{g}$, respectively.

The use of a combination of peginterferon alfa- $2 \mathrm{a}$ and ribavirin will require evaluation by direct comparison with a combination of standard interferon and ribavirin. Although a phase 2 study of peginterferon alfa-2a and ribavirin has been conducted, full results are not yet available. ${ }^{20}$

Supported by a grant from F. Hoffmann-LaRoche, Basel, Switzerland. 
Dr. Heathcote is a member of an advisory board for F. HoffmannLaRoche. Dr. Shiffman is a speaker for Schering-Plough, Amgen, and F. Hoffmann-LaRoche and is on the advisory boards for Roche Molecular Systems and F. Hoffmann-LaRoche. Dr. Dusheiko has served as a consultant to Schering-Plough, F. Hoffmann-LaRoche, and Yamanouchi and Amgen. Dr. Lee is a consultant to and participates in speakers' bureaus for SmithKline Beecham, Glaxo Wellcome, and F. Hoffmann-LaRoche. Dr. Reindollar is a speaker for Schering-Plough and F. Hoffmann-LaRoche. Dr. Reddy is a speaker for Schering-Plough, Amgen, and F. HoffmannLaRoche and is on advisory boards for Roche Molecular Systems and F. Hoffmann-LaRoche. Dr. Wright is a speaker for and is on an advisory board for F. Hoffmann-LaRoche.

We are indebted to Dr. Sugantha Govindarajan of Rancho Los Amigos Medical Center (Downey, Calif.) for her work as the study pathologist.

\section{APPENDIX}

In addition to the authors, members of the study group who participated in this study were V. Bain, University of Alberta, Edmonton, Canada; M.F. Bassendine, Freeman Hospital, Newcastle upon Tyne, United Kingdom; C.L. Berg, University of Virginia Health System, Charlottesville; T.D. Boyer, Emory University School of Medicine, Atlanta; M. DeMicco, Associated Gastroenterology Medical Group Clinical Research, Anaheim, Calif.; P. Desmond, St. Vincent's Hospital, Melbourne, Victoria, Australia; G. Farrell, Westmead Hospital, Westmead, Australia; M. Fried, University of North Carolina, Chapel Hill; K. Lindsay, Ambulatory Health Center University of Southern California, Los Angeles; P.F. Malet, University of Texas Southwestern Medical Center, Dallas; P. Martin, UCLA School of Medicine, Los Angeles; G.Y. Minuk, Health Sciences Centre, Winnipeg, Man., Canada; D.K. Moonka, Henry Ford Hospital, Detroit; N.V. Naoumov, University College London Medical School, London; J. O'Grady, King's College School of Medicine and Dentistry, London; S. Pedder and B.P. Rae, Hoffmann-LaRoche, Nutley, N.J.; P.J. Pockros, Scripps Clinic, La Jolla, Calif.; W. Rosenberg, University of Southampton School of Medicine, Southampton, United Kingdom; S. Ryder, Queen's Medical Center, Nottingham, United Kingdom; M. Sherman, Toronto General Hospital, Toronto; C. Smith, Minnesota Clinical Research Center, St. Paul; H.C. Thomas, St. Mary's Hospital, London; and S. Whalley, Royal Free Hospital, London. Members of the Safety Review Board were C. Ghent, University of Western Ontario, London, Ont., Canada; E. Krawitt, University of Vermont Medical Center, Burlington; and J. Rakela, Mayo Clinic Scottsdale, Scottsdale, Ariz.

\section{REFERENCES}

1. Cooksley WGE, Dudley FJ, Watson K. Treatment of cirrhotic hepatitis C virus patients with daily doses of interferon- $\alpha 2$ a. J Viral Hepat 1997; Suppl 2:75-8.

2. Poynard T, Marcellin P, Lee SS, et al. Randomised trial of interferon $\alpha 2 \mathrm{~b}$ plus ribavirin for 48 weeks or for 24 weeks versus interferon $\alpha 2 \mathrm{~b}$ plus placebo for 48 weeks for treatment of chronic infection with hepatitis $\mathrm{C}$ virus. Lancet 1998;352:1426-32

3. McHutchison JG, Gordon SC, Schiff ER, et al. Interferon alfa-2b alone or in combination with ribavirin as initial treatment for chronic hepatitis $\mathrm{C}$. N Engl J Med 1998;339:1485-92.
4. Ascione A, De Luca M, Canestrini C, et al. Efficacy of high dose of recombinant alpha $2 \mathrm{~b}$ interferon on long term response in chronic hepatitis $\mathrm{C}$ and cirrhosis: perspective randomized multicentre study. Ital J Gastroenterol Hepatol 1998;30:517-23.

5. Poynard T, Moussali J, Ratziu V, et al. Is antiviral treatment (IFN alpha and/or ribavirin) justified in cirrhosis related to hepatitis $\mathrm{C}$ virus? Acta Gastroenterol Belg 1998;61:431-7.

6. Schalm SW, Weiland O, Hansen BE, et al. Interferon-ribavirin for chronic hepatitis $\mathrm{C}$ with and without cirrhosis: analysis of individual patient data of six controlled trials. Gastroenterology 1999;117:408-13.

7. Valla DC, Chevallier M, Marcellin P, et al. Treatment of hepatitis C virus-related cirrhosis: a randomized, controlled trial of interferon alfa- $2 \mathrm{~b}$ versus no treatment. Hepatology 1999;29:1870-5.

8. Shiratori Y, Yokosuka O, Nakata R, et al. Prospective study of interferon therapy for compensated cirrhotic patients with chronic hepatitis C by monitoring serum hepatitis C RNA. Hepatology 1999;29:157380 .

9. Xu Z-X, Hoffman J, Patel I, Joubert P. Single-dose safety/tolerability and pharmacokinetic/pharmacodynamics (PK/PD) following administration of ascending subcutaneous doses of pegylated-interferon (PEG-IFN) and interferon $\alpha$-2a (IFN $\alpha$-2a) to healthy subjects. Hepatology 1998;28: Suppl:702A. abstract.

10. Algranati NE, Sy S, Modi M. A branched methoxy $40 \mathrm{kDa}$ polyethyl ene glycol (PEG) moiety optimizes the pharmacokinetics $(\mathrm{PK})$ of peginter feron $\alpha$-2a (PEG-IFN) and may explain its enhanced efficacy in chronic hepatitis C (CHC). Hepatology 1999;30:Suppl:190A. abstract. 11. Shiffman M, Pockros PJ, Reddy RK, et al. A controlled, randomized, multicenter, descending dose phase II trial of pegylated interferon alfa-2a (PEG) vs standard interferon alfa-2a (IFN) for treatment of chronic hepatitis C. Gastroenterology 1999;116:A1275. abstract.

12. Zeuzem $S$, Feinman $S V$, Rasenack $J$, et al. Peginterferon alfa-2a in patients with chronic hepatitis C. N Engl J Med 2000;343:1666-72.

13. Lai MY, Kao JH, Yang PM, et al. Long-term efficacy of ribavirin plus interferon alfa in the treatment of chronic hepatitis C. Gastroenterology 1996;111:1307-12.

14. International Conference on Harmonization: draft guidance on spec ifications, test procedures, and acceptance criteria for biotechnological/biological products — FDA notice. Fed Regist 1998;63:31506-13.

15. Germer JJ, Rys PN, Thorvilson JN, Persing DH. Determination of hepatitis $\mathrm{C}$ virus genotype by direct sequence analysis of products generated with the Amplicor HCV test. J Clin Microbiol 1999;37:262530 .

16. Knodell RG, Ishak KG, Black WC, et al. Formulation and application of a numerical scoring system for assessing histological activity in asymptomatic chronic active hepatitis. Hepatology 1981;1:431-5.

17. Everson GT, Jensen DM, Craig JR, et al. Efficacy of interferon treatment for patients with chronic hepatitis $\mathrm{C}$ : comparison of response in cirrhotics, fibrotics, or nonfibrotics. Hepatology 1999;30:271-6.

18. Idilman $\mathrm{R}$, De Maria $\mathrm{N}$, Colantoni $A$, Dokmeci $A$, Van Thiel $D H$. Interferon treatment of cirrhotic patients with chronic hepatitis C. J Viral Hepat 1997;4:81-91.

19. Shiffman ML, Hofmann CM, Thompson EB, et al. Relationship between biochemical, virological, and histological response during interferon treatment of chronic hepatitis C. Hepatology 1997;26:780-5.

20. Sulkowski M, Reindollar R, Yu J. Combination therapy with peginterferon $\alpha$-2a (PEG-IFN) and ribavirin in the treatment of patients with chronic hepatitis C (CHC): a phase II open-label study. Hepatology 1999 ; 30:Suppl:197A. abstract. 